\title{
SEM observation of grain boundary structures in quartz-iron oxide rocks deformed at intermediate metamorphic conditions
}

\author{
LEONARDO LAGOEIRO and CRISTIANE C. GONÇALVES \\ Departamento de Geologia/UFOP, campus - Morro do Cruzeiro, s/n, 3540-0000 Ouro Preto, MG, Brasil \\ Manuscript received on September 13, 2009; accepted for publication on December 6, 2010
}

\begin{abstract}
Several studies have demonstrated the effect of a second phase on the distribution of fluid phase and dissolution of quartz grains. However, as most observations came from aggregates deformed under hydrostatic stress conditions and mica-bearing quartz rocks, 3-D distribution of pores on quartz-quartz (QQB) and quartz-hematite boundaries (QHB) has been studied. Several fracture surfaces oriented according to finite strain ellipsoid were analyzed. The pore distribution characterizes the porosity and grain shape as highly anisotropic, which results from the nature and orientation of boundaries. QHB have physical/chemical properties very different from QQB, once the hematite plates have strong effect on wetting behavior of fluid, likewise micas in quartzites. They are pore-free flat surfaces, normal to compression direction, suggesting that they were once wetted with a continuous fluid film acting as faster diffusion pathway. At QQB, the pores are faceted, isolated, close to its edges reflecting the crystallographic control and an interconnected network of fluid along grain junctions. The QQB facing the extension direction are sites of fluid concentration. As consequence, the anisotropic dissolution and grain growth were responsible for the formation of hematite plates and tabular quartz grains significantly contributing for the generation of the foliation observed in the studied rocks.
\end{abstract}

Key words: deformation mechanisms, fluid distribution, grain growth, porosity, solution transfer.

\section{INTRODUCTION}

Several studies based on observations (Mancktelow 1987, Hippertt 1993, 1994) and experiments (Hickman and Evans 1995, Farver and Yund 1999) have demonstrated that the presence of a second phase has a profound effect on the anisotropic distribution of fluid phase and the dissolution of quartz minerals. Most experiments carried out in aggregates deformed under conditions of hydrostatic stress have demonstrated that fluid distributions are in textural equilibrium, showing equilibrated pore geometries (e.g. Watson and Brenan 1987). These studies have presented wetting and nonwetting fluid distributions (interconnected tubules along grain edges and isolated pores, respectively) as well as continuous fluid film in equilibrium with the solid

Correspondence to: Cristiane C. Gonçalves

E-mail: cristiane@degeo.ufop.br / cristianegeologa@hotmail.com phases along grain boundaries (Watson and Brenan 1987, Lee et al. 1991). However, for rocks naturally deformed, data have shown a heterogeneous fluid distribution, out of textural equilibrium, due to highly anisotropic interfacial energy in the polymineralic aggregates (Spry 1983, Urai et al. 1986, Hippertt 1994, Jin et al. 1994, Daines and Kohlstedt 1997). In addition, the deformation-induced change in fluid distribution may have a profound effect on the rock strength, deformation mechanism and fluid transport (Hirth and Tullis 1991, Tullis et al. 1996).

However, the majority of the observations in naturally deformed rocks have been made exclusively on mica-bearing quartz rocks (e.g. Hippertt 1994). Thus, in this study samples of iron oxide bearing quartz rocks from Paleoproterozoic banded iron formations were selected to investigate the influence of a second phase on the distribution of aqueous fluid, as inferred from the 
3-D distribution of pores on quartz-quartz and quartzhematite boundaries. The samples were carefully prepared to ensure that fractures would occur exclusively along grain boundaries. Then, several fracture surfaces carefully oriented with respect to the finite strain ellipsoid were observed in the scanning electron microscope (SEM). The studied banded iron formations occur in the southern part of the Brazilian Archean-Proterozoic shield, São Francisco Craton (Fig. 1). In this location there is an extensive iron ore deposit, in the region termed Quadrilátero Ferrífero - QF, which is part of a granite-greenstone terrain of Archaean-Proterozoic age (Alkmim and Marshak 1998).

\section{GEOLOGICAL SETTING}

The studied quartz-iron oxide samples came from Paleoproterozoic iron formations from $\mathrm{QF}$ area (Fig. 1). The region is characterized as a classical granite-greenstone terrain, composed mainly of a sequence of metavolcanic and metasedimentary rocks, surrounded by a 2.9$3.2 \mathrm{Ga}$ gneiss/migmatite complex (Teixeira et al. 1989, Machado et al. 1996), and Archaen plutons (2.7-2.6 Ga) (Teixeira 1985, Machado and Carneiro 1992, Marshak et al. 1992, Carneiro et al. 1994, 1995, Machado et al. 1996). According to the referred authors, it is a complex association of granite and gneiss-migmatite rocks, covered by a meta-volcanic-sedimentary sequence (Rio das Velhas Supergroup). Discordantly overlying this basement sequence, there are metasedimentary rocks of paleo-Proterozoic age, which comprise the Minas Supergroup (Carneiro et al. 1995, Noce 1995, Renger et al. 1995, Alkmim and Marshak 1998). The overlying Paleoproterozoic units are composed of metasediments including schist, quartzite, carbonate rocks and a several hundred-meter thick unit of banded iron formations (BIF's). These units were deposited ca $2.5 \mathrm{Ga}$ (Babinsk et al. 1993).

The supracrustal sequences have been intensively folded in a complex geometry consisting of kilometerscale synclines and anticlines surrounded by domes of gneiss/migmatite (Marshak et al. 1992, Alkmim and Marshak 1998). The contacts between the domes and the supracrustal rocks are generally marked by low to medium grade metamorphic shear zones (Hippertt et al. 1992). In several of these contacts thermal aureoles are observed, with the development of porphyroblasts in the relatively cooler supracrustal rocks (Herz 1970, 1978, Jordt-Evangelista et al. 1992). Some authors have proposed a compartmentation of QF region according to the magnitude of deformation (Rosière et al. 2001) and metamorphic grade (Pires 1995). According to these authors, in the west part of the QF area, the less deformed rocks outcrop and metamorphic studies indicate a metamorphism not higher than the low greenschist facies, reaching temperatures up to $350^{\circ} \mathrm{C}$. On the other hand, in the eastern domains, rocks are intensely deformed and mineral association in some country rocks suggests temperatures around $500^{\circ} \mathrm{C}$, compatible with a metamorphism of higher greenschist to lower amphibolite facies. Between these two extremes, structures and metamorphic mineral association indicate an intermediate strain and metamorphic grade (Pires 1995, Rosière et al. 2001).

The BIF's occur all over the QF area and mark a consistent and pervasive unit consisting in an important stratigraphic marker. Basically, the BIF's consist of banded rocks of quartz and iron oxide layers, with tabular to lens shape, alternating rhythmically. They show pervasive foliation, coincident with the banding, defined by well-developed platy hematite. The thickness of individual layers varies from few to several millimeters and the major constituents are quartz, magnetite and hematite. The studied samples were collected in the east boundary of QF (Fig. 1) region. There are several shear zones developed parallel to the compositional layering, whose kinematic indicators, such as S-C foliation, are all consistent with an interlayer reverse shear sense with up-dip mineral lineation. The quartz domains are lens shaped and frequently display a sigmoidal and asymmetrical geometry, most of them parallel to the compositional layering (Fig. 2a).

\section{METHODS}

The microstructural features were described by optical microscopy using regular thin sections. The quartz $c$ axes orientations were measured in a U-stage mounted on an optical microscope (Passchier and Trouw 1996). The orientation pattern of hematite grains was obtained using the SEM-EBSD system (Prior et al. 1999). In addition, we have used SEM techniques to analyze the 


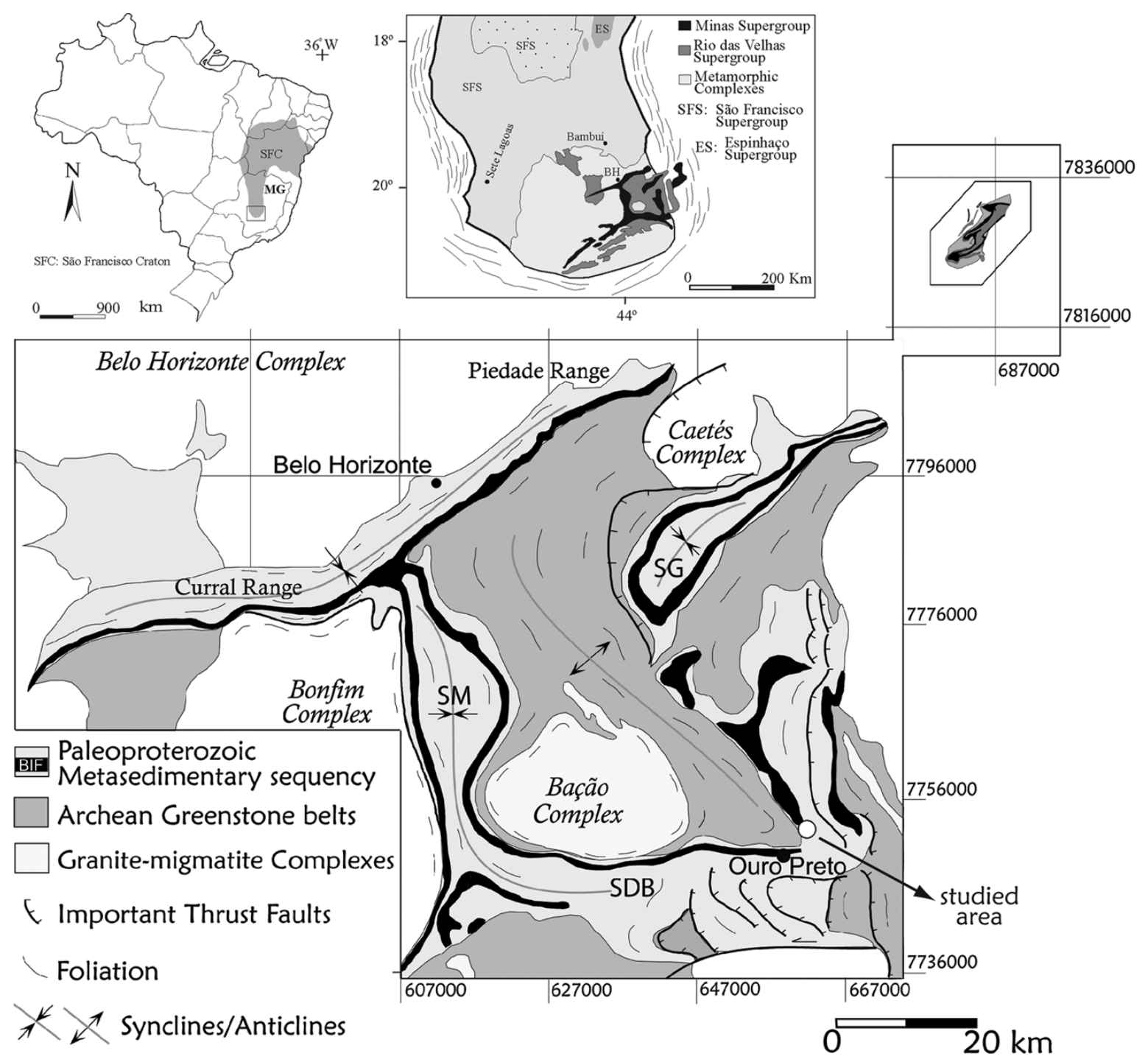

Fig. 1 - Simplified geological map of the Quadrilátero Ferrífero region in the southern margin of the São Francisco Craton (SFC). Location of the studied area is indicated by the white circle (BH: Belo Horizonte, SM: Moeda Syncline, SDB: Dom Bosco Syncline, SG: Gandarela Syncline) (after Dorr II 1969 and Alkmim and Marshak 1998).

morphology and distribution of pores on grain boundaries in a similar way as described in Watson and Brenan (1987), Lee et al. (1991) and Hippertt (1994). We have inferred the distribution of aqueous fluid based on the distribution of pores in sections cut parallel to the principal planes of the finite strain ellipsoid, i.e., XY, parallel to foliation, $\mathrm{XZ}$ and $\mathrm{YZ}$, perpendicular to foliation and parallel and perpendicular to the mineral lineation, respectively.

All sections for SEM examination were prepared by carefully fracturing thin plates of rocks to ensure that the fractures occur exclusively at grain boundaries.
After that, the fracture surfaces were cleaned with pressurized gas to blown small fragments off. Fractured surfaces were then gold coated and examined by SEM (SEM JEOL 5510) operated at $25 \mathrm{kV}$, at Microscopy Laboratory - Geology Department, Federal University of Ouro Preto.

\section{OPTICAL MICROSTRUCTURES}

Optical thin sections were observed in XZ planes, i.e. perpendicular to the foliation and parallel to the lineation. The pervasive foliation in these tectonites is characterized by an alternation of platy-hematite layers 

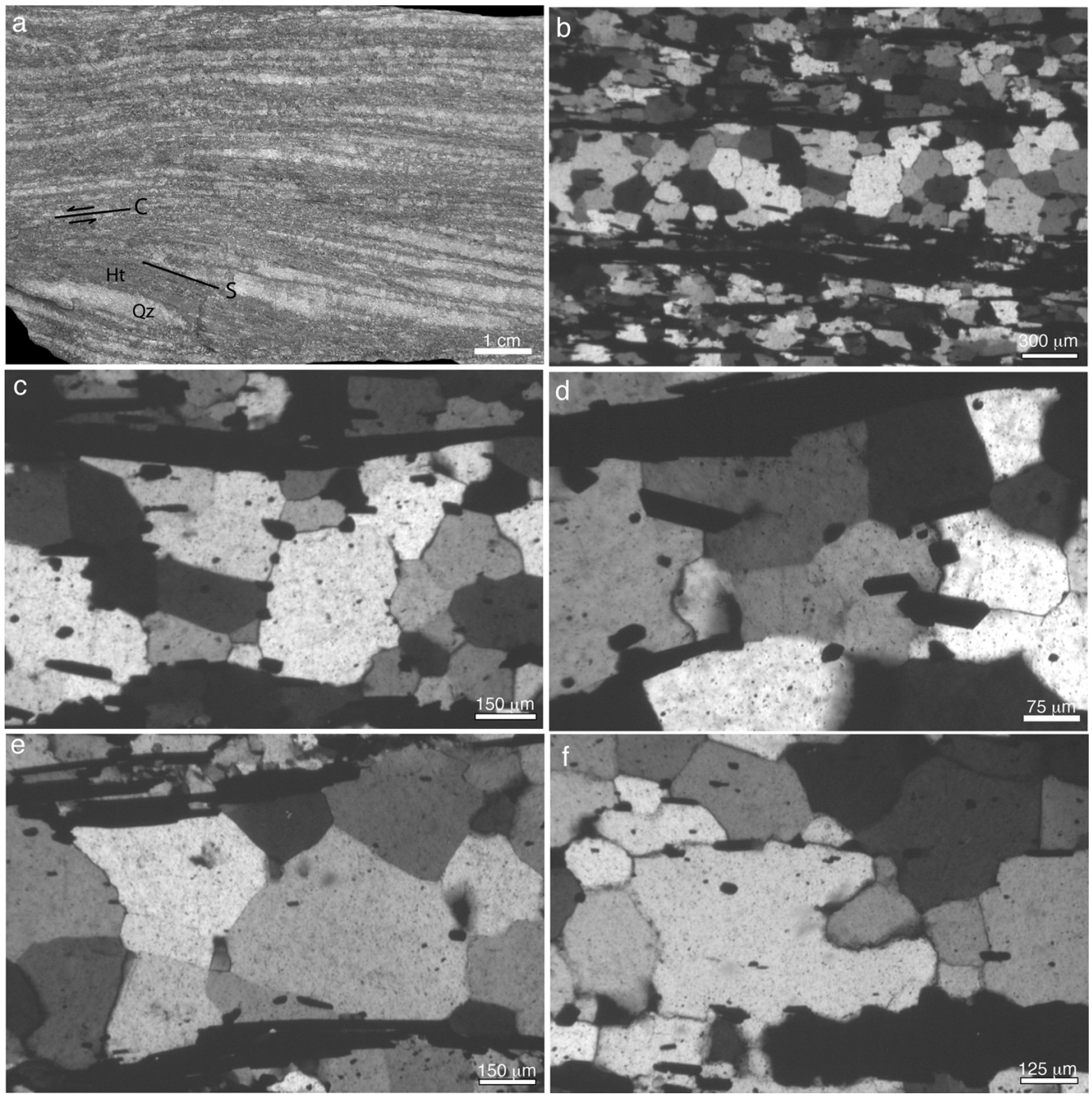

Fig. 2 - Thin section photomicrographs observed in XZ planes, i.e. perpendicular to the foliation and parallel to the stretching lineation. (a) Hand sample showing discontinuous compositional banding where quartz (Qz) layers (white) alternate with hematite (Ht) layers (gray). Interlayer shear bands indicate a reverse sense of shear. (b) Micrograph taken under crossed polarizers displaying the pervasive foliation characterized by an alternation of platy-hematite layers with quartz-rich layers. The thickness of these layers is quite variable, ranging from few microns up to several millimeters. (c) Detail of micrograph in (b) showing the concentration of hematite inclusions on quartz boundaries. (d) Detail showing hematite inclusions. Most hematite grains have well-developed faces with a characteristic rhombic section. (e) In some layers quartz grains are large with straight boundaries meeting at triple junctions. (f) In other layers quartz grains are large and have highly irregular boundaries. Some grains appear to be migrating over the small grains as shown in (f).

with quartz-rich layers (Fig. 2a and 2b). The thickness of these layers varies from a few microns to several millimeters. The hematite grains have shapes varying from tabular to platy. They have a wide range of sizes, from a few microns to a few millimeters and several of them are included in large quartz grains (Fig. 2c). The included hematite grains show well-developed faces (rhomb sections) and their average size is about $50 \mu \mathrm{m}$. They are commonly found close to the boundaries of the host quartz.

Both, the hematite grains in the matrix (hematite plates) and the included hematite grains (hematite platelets) have a strong shape preferred orientation (Fig. 2d) as well as crystallographic orientation with their $c$-axes 
concentrated at the foliation pole (Fig. 3a). Quartz grains in quartz-rich layers have a wide range of sizes and shapes. There is a polymodal distribution of sizes between $20 \mu \mathrm{m}$ and $2 \mathrm{~mm}$. Shapes vary from tabular (aspect ratio up to 10:1) to granular. Grain boundaries are also characterized by a variety of geometries. Some grains have straight boundaries (Fig. 2e), whereas others have slight to pronounced curvatures (Fig. 2f). Several observed grains have irregular boundaries and the lobate shapes predominate. Irregular boundaries preferentially occur on faces at a high angle to the direction of maximum elongation ( $X$-axis of the finite strain ellipsoid), on which small inclusions of euhedral hematite grains occur. On the other hand, boundaries of inequant quartz grains normal to the maximum compression tend to be straight and free of inclusions.

\section{MicRofABRIC DATA}

In general, quartz grains have strong $c$-axis preferred orientation with a maximum close to $Y$-axis (Fig. 3b), differently from orientation pattern observed for hematite grains (Fig. 3a). Undulose extinctions consist of broad stripes oriented obliquely to the compositional banding. In addition, the grain boundaries are also preferentially oriented. The pole figure and rose diagram in Figure 3 show the orientation pattern of grain boundary segments according to sample reference system and black stripes in the rose diagram highlight the segments parallel and sub-parallel to foliation pole ( $\mathrm{Z}$ direction). The grain boundary segments are preferentially oriented sub-parallel to the rock foliation and, secondarily, they are oriented normal to this structure (Fig. 3c, detail in the left side). As the segments sub-parallel to $\mathrm{Z}$ direction must represent grain boundaries parallel and sub-parallel to YZ section or those normal to direction of maximum extension ( $\mathrm{X}$ direction), their orientation according to quartz crystal reference system was determined. Thus, the angles between the grain boundary pole represented by the segments highlighted and the $c$-axes of the grains limited for them were determined (Fig. 3c, histogram).

The distribution of angles between $c$-axes and grain boundary poles show a preponderance of values between $50^{\circ}$ and $80^{\circ}$, although the higher concentrations are observed between 50 and $55^{\circ}$. Angular relations higher than $80^{\circ}$ also occur and those shorter than $33^{\circ}$ are scarce.
According to quartz crystal reference system (Gonçalves and Lagoeiro 2009a), the observed distribution pattern characterizes the quartz-quartz grain boundaries normal to direction of maximum extension (sub-parallel to $\mathrm{YZ}$ sections) as surfaces belonging to rhombohedral and trapezohedral girdles, preferentially. As indicated by the orientation patterns of $c$-axes, prismatic surfaces are common, while boundaries oriented according to basal planes do not occur parallel to the YZ section. In a general way, boundaries whose poles are at low angle to the $c$-axes are rare (Fig. 3c, histogram).

\section{SEM MICROSTRUCTURES AND THEIR IMPLICATIONS}

SEM images (Fig. 4), in three perpendicular sections, $\mathrm{XY}, \mathrm{XZ}$ and YZ, reveal the pore distribution and grainboundary topography showing that fracture surfaces in the iron formation rocks reveal a complex set of pores and grain boundary structures. Since almost $100 \%$ of the fracture surfaces are intergranular grain surfaces, the observed structures provide insights into the syndeformational interactions between pores (fluid) and grain boundaries.

\section{QUARTZ-HEMATITE BOUNDARIES IN XY SECTIONS}

Quartz grain boundaries in contact with hematite plates oriented normal to the maximum compression direction (i.e. XY sections) are typically flat and pore-free (Fig. 4a). In principle the absence of pores and flat quartz boundaries in the XY sections cannot be used to distinguish between a dry boundary and one containing a fluid. It is well know that it is possible to get fluid films on grain boundaries in rocks undergoing deformation, but once the deformation has stopped the fluid film breaks up into isolated inclusions (Urai et al. 1986, Jin et al. 1994, Daines and Kohlstedt 1997). However, the boundaries in the XY sections are perfectly flat and no isolated pores were observed on them. Two possibilities are envisioned to explain why these boundaries do not have any porosity and their surfaces are perfectly flat.

The absence of pores and the flat nature of the boundaries might suggest the presence of a very thin fluid film ( $<2 \mathrm{~nm}$, c.f. Raj 1982; wetting angle $\theta \approx 0^{\circ}$, i.e. grain surface wetted by the fluid). Such thin aqueous fluids are likely to be highly structured and may exert a profound influence on the kinetics of intergranular pressure solution. Therefore, the surfaces might be 

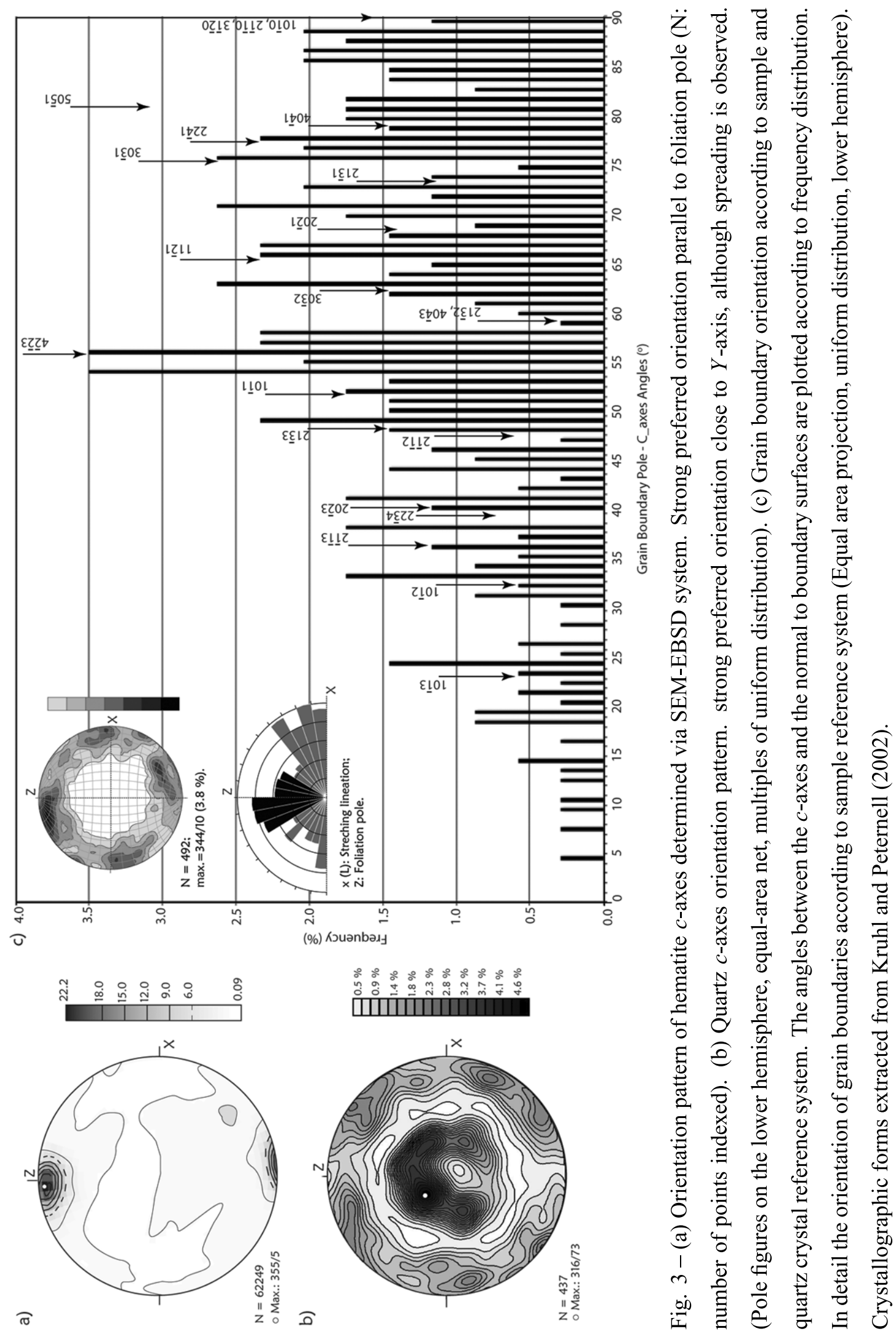

An Acad Bras Cienc (2011) 83 (3) 

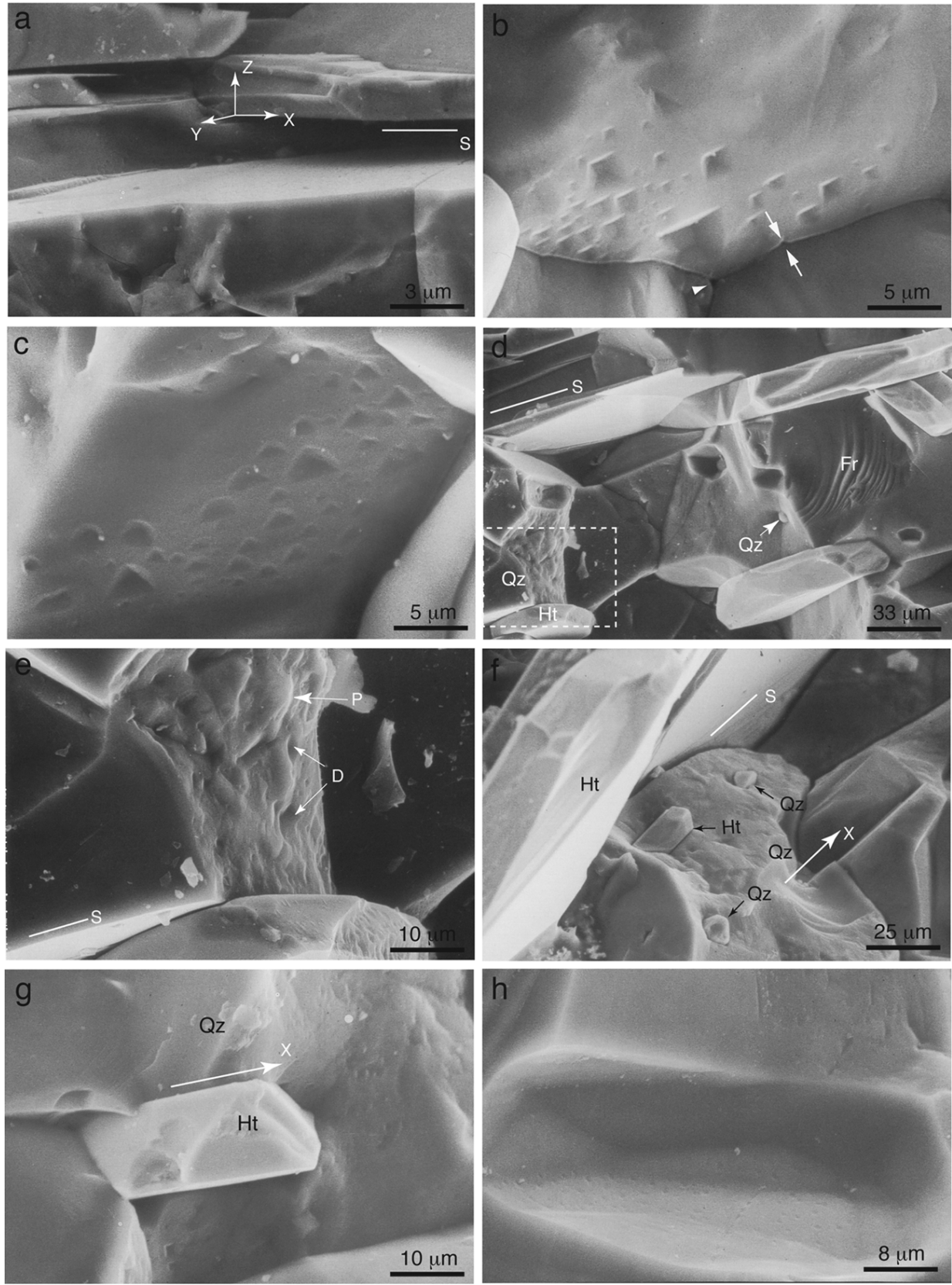

Fig. 4 - SEM micrographs showing quartz grain boundaries on differently oriented interfaces with respect to the directions of the finite strain ellipsoid. Bulk foliation trace, S, is shown in the figure. (a) Quartz grain boundaries in contact with hematite plates oriented normal to the maximum compression direction (XY sections); these phase boundaries are typically flat with no pores. (b) and (c) Grain boundaries parallel to the XZ planes exhibit isolated non-connected pores. Both triangular (with curved sides and concave bottom) (b) and pyramidal (with flat bottom) shapes (c) are common. The arrows in picture (b) indicate that pores are closed to the grain edges and the occurrence of openings and voids. (d) Profusion of pores along boundaries facing the direction of maximum extension (approximately parallel to the YZ section). The arrow indicates a new quartz (Qz) grain precipitated inside a pore. $F r$ is an artifact produced during sample preparation. A detail of micrograph (d, Ht: Hematite) is shown in (e). Protusions (P) and depressions (D) are indicated. (f) New grains (hematite, Ht, and quartz, Qz) inside pores in the host quartz grain are indicated by arrow. The small grains are faceted and have a shape preferred orientation (SPO) parallel to the stretching direction. (g) Faceted hematite (Ht) grain with perfect rhombohedral faces (Qz: quartz grain). Some hematite grains have been plucked off together with quartz leaving impressions (negative crystals) on the opposing quartz boundary as shown in (h). 
wetted with thin fluid when the rock was being actively deformed, but the deformation had stopped and the thin film split up into isolated inclusions. The absence of porosity on the surfaces might be explained by postkinematic textural adjustment due to static recrystallization accommodated by dry grain boundary or intragrain diffusion. In this case the present grain boundary microstructures are not exactly those of the peak of metamorphism and deformation. However, the static recrystallization might be expected to occur in phase or grain boundaries with different orientations with respect to the bulk strain ellipsoid, namely XZ and YZ planes, which are decorated with pores and inclusions of wellformed hematite or quartz grains, as described in the next sections.

Another possibility is that the phase boundaries (XY orientation) were dry when grains were actively deformed or at least in the late stage of deformation and the nature of the phase boundaries result from the contact between flat hematite face (mostly basal planes) with quartz grains. It is worth to note that the majority of quartz grains show $c$-axes oriented preferentially around the $Y$-axis of the finite strain ellipsoid what imply that basal (0001) faces of hematite grains (Fig. 3a) are in contact with prismatic $\{10-10\}$ faces of quartz grains. Besides, the theory of crystal growth shows that faces that grow slowly will be dissolved slowly (Tullis 1989). Then, would be more difficult to dissolve the quartz grains whose prismatic planes are perpendicular to direction of maximum compression ( $\mathrm{Z}$ direction). Therefore, the pores should be rare in the XY surfaces, naturally, and the presence of hematite plates should increase the difficulty to generate them.

\section{Quartz Grain Boundaries Parallel to the}

XZ Planes

Quartz-quartz boundaries observed in XZ sections show a distribution of regular faceted isolated pores. Depending on the face where the pores occur, triangular or pyramidal forms predominate (Fig. $4 \mathrm{~b}$ and c). Grain boundary topographies on faces parallel to $\mathrm{XZ}$ sections are predominantly flat. The pores commonly have regular shapes with faceted sides indicating crystallographically controlled shapes (Wegner and Christie 1983). Pyramidal (with flat bottom) and triangular (with curved sides and concave bottom) shapes are common (Fig. $4 \mathrm{~b}$ and
Fig. $4 \mathrm{c}$, respectively). They vary in size from $1 \mu \mathrm{m}$ to $5 \mu \mathrm{m}$ and are relatively deep ( $3 \mu \mathrm{m}$ in depth for large pores). The straight sides of the observed forms (Fig. $4 \mathrm{~b}$ ), as well as the round forms, characterize the XZ quartz surfaces as basal planes, mainly (O’Donoghue 1987, Hippertt 1994), as indicated for the $c$-axes preferred orientation pattern (Fig. 3b). On the other hand, the occurrence of triangular pores formed by straight and curved sides (Fig. 4c) is related to those grains oriented at high angle to the foliation, once this pore geometry characterize rhombohedral boundaries (O'Donoghue 1987, Hippertt 1994) parallel to XZ surfaces.

The regular form of the pores indicates, besides the crystallographic control (Wegner and Christie 1983), that a thermodynamic equilibrium between solid-fluid was achieved along these boundaries. The presence of isolated pores indicates a non-wetting fluid distribution (Lee et al. 1991) or that the fluid phase on these quartz grain boundaries did not exist as a continuous film. However, pores generally occur close to three- (indicated by arrows in Fig. 4b) and four-grain junctions (arrow head in Fig. 4b). This kind of concentration of pores, in addition to the presence of openings along three-grain junctions and voids at four-grain junctions, indicates that the aqueous fluid phase may also have resided along the quartz three-grain junctions (grain edge channels). It might have existed as a continuous interconnected fluid network, with fluid at two-grain junctions confined to isolated pores.

QUARTZ-QUARTZ INTERFACES FACING THE DIRECTION OF MAXIMUM EXTENTION (YZ SECTIONS)

In contrast, pores along boundaries facing the direction of maximum extension (approximately parallel to the YZ section) are abundant. These interfaces are characterized by highly irregular topographies where 'protrusions' and 'depressions', as well as irregular pores predominate (Fig. 4d, e and f). Pores on these boundaries are highly irregular in shape and $20 \mu \mathrm{m}$ across. Features that resemble protrusions are separated for large isolated depressions or pores and the height of the protrusions above depressions varies and may reach up to $4 \mu \mathrm{m}$. Depressions observed on grain surfaces on one face of a fracture are not complemented by protrusions, which would fill these depressions on the other face of the fracture. 
Small hematite and quartz grains occur inside some of the pores. They are predominantly faceted and have shape preferred orientation (SPO) with their longest axes oriented in the direction of maximum extension ( $X$-axis) (Fig. $4 \mathrm{f}$ and g). Grain sizes inside the pores may vary from few $\mu \mathrm{m}$ to $20 \mu \mathrm{m}$. They are generally well formed with distinct crystallographic forms (Fig. 4g). In some micrographs hematite grains have been plucked off together with quartz leaving their impression (negative crystal) on the opposing quartz boundary (Fig. 4h). Some of these negative crystals exhibit perfect rhombic shapes of the hematite grains.

The quartz host grain boundaries with inclusions, irregular topography and pores are commonly present where quartz grains are in contact with larger hematite plates parallel to the bulk foliation (Fig. 4f). The irregular shape of the pores indicates that fluid at these boundaries was not in thermodynamic equilibrium with the solid. Moreover, the presence of precipitated quartz and hematite grains inside the larger pores indicates that aqueous fluid at these boundaries was saturated in $\mathrm{Si}$ $\left(\mathrm{SiO}_{2}\right)$ and $\mathrm{Fe}\left(\mathrm{Fe}_{2} \mathrm{O}_{3}\right)$. These features imply that grain boundaries normal to the direction of maximum extension are sites of preferential fluid concentration. In addition, the irregular topography of these boundaries indicates that substantial grain growth may have occurred parallel to the direction of maximum extension (grain boundary migration).

It is well known that the crystallographic orientation and the presence of water (and other aqueous fluids) have a significant effect on grain boundary mobility (Urai et al. 1986, Karato 1989). The new precipitated grains grow with their $c$-axes aligned parallel to the maximum extension direction, indicating that under conditions where fluid phase is in contact with the growing boundaries, grains oriented with basal planes approximately normal to the extension direction grow faster (Tullis 1989, Hippertt 1994). Then, the growth is faster in some crystallographic directions than others.

However, when the host grains in the studied samples are considered some discrepancies occur and it is necessary to consider that the grain growth presumably involves mass transport in the quartz-water system through a fluid phase or along grain surfaces (Tullis and Yund 1982). Thus, the growth for the host grains oc- cur parallel to the maximum extension direction, but differently from the new precipitated grains, through the migration of grain surfaces whose poles make high angles with the $c$-axes. The migrating quartz boundaries (large non-precipitated host grains) make, preferentially, angles higher than $50^{\circ}$ with the $c$-axes and then they should represent rhombohedral, trapezohedral and prismatic faces (Fig. 3c). Those boundaries that make less than $10^{\circ}$ with the $c$-axes compound only $1.0 \%$ of the boundaries whose orientation was measured and only $8.5 \%$ of the data present angles smaller than $30^{\circ}$ (Fig. 3c). Therefore, basal and sub-basal faces parallel to $\mathrm{YZ}$ surfaces are rare, for the host grains.

The higher solubility of quartz in the fluid boundary (YZ surfaces) may promote grain boundary migration since water dissolved in quartz lattice enhances solidstate kinetics (dislocation motion and diffusion). The tiny entrapped hematite grains included in the YZ faces of quartz grains should exert a dragging effect on the migrating quartz boundaries. The presence of hematite grains inside the boundaries increases the interfacial free energy of the grain, because they promote an increase in the interfacial area as the grain boundary advances and traps the hematite grains. However, the dragging effect of hematite grains on growing grain boundary may be overcome by the higher solubility of quartz faces in contact with fluid, hence enhancing the grain boundary mobility, i.e., the rate which the material (atoms) can transfer through the grain boundary (according to $\mathrm{X}$ direction).

\section{DISCUSSION}

The different pore topographies observed along boundaries with different orientations and the anisotropic distribution of pores along these boundaries may suggest that the fluid distribution and grain boundary structures in these rocks were highly anisotropic. Furthermore, on boundaries oriented at high angle to the $X$-axis, precipitated hematite grains suggest that these boundaries were sites of preferential precipitation (Fig. 5).

A physical model (Fig. 5) to explain the anisotropic fluid distribution and grain growth is proposed. It takes into account the microstructures observed in thin sections, the distribution and characterization of pores, as well as the grain boundary structures along the three 


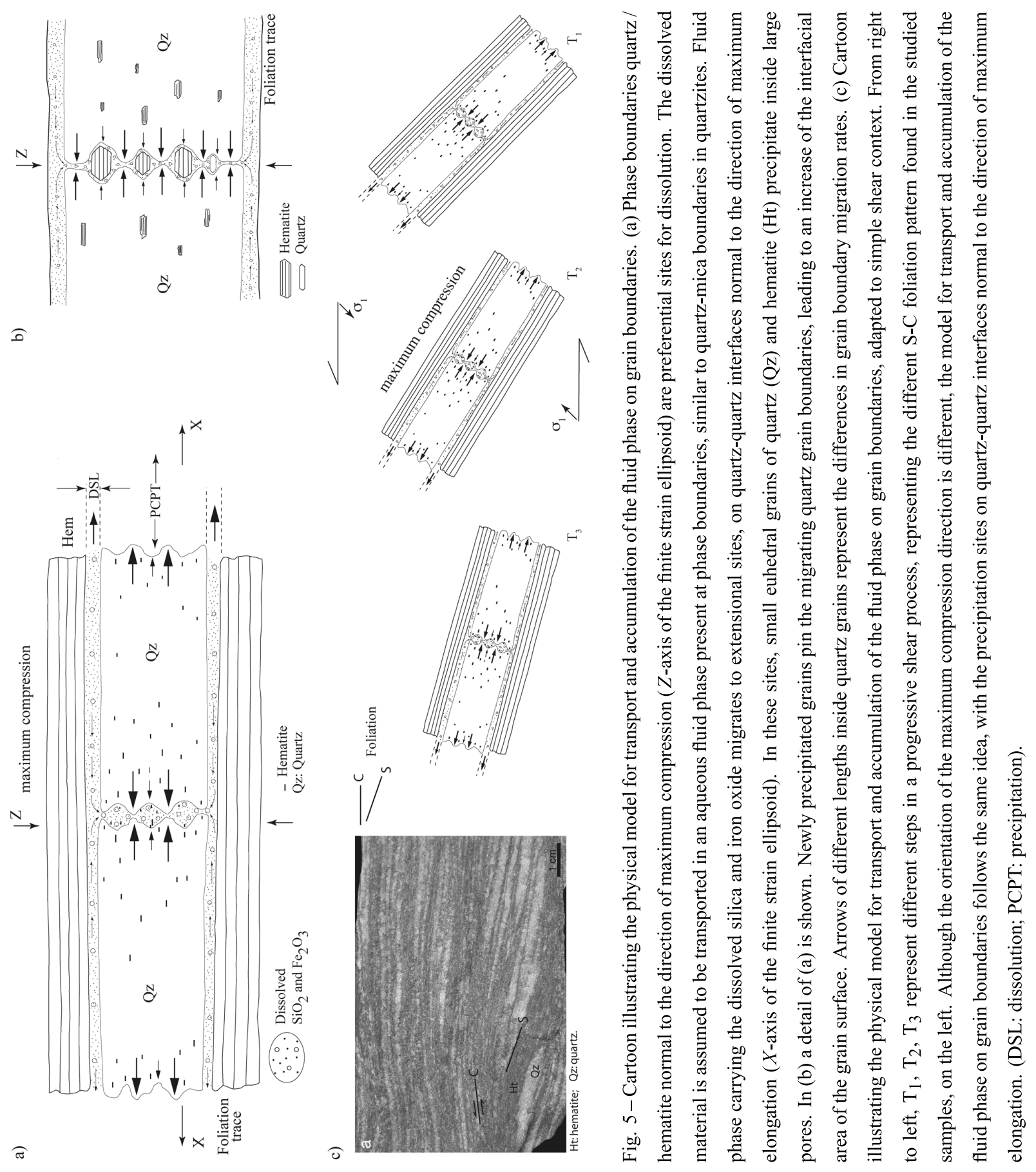


different sections studied (i.e. XY, XZ and YZ planes of the finite strain ellipsoid).

\section{FLuid Distribution AND DRIVING ForCE For GRAIN GROWTH}

We interpret the pore structures observed in these rocks as a result of anisotropic distribution of aqueous fluid along grain boundaries. The presence of quartz host grains having straight or smoothly curved grain boundaries, in addition to the presence of included small hematite grains close to the boundaries facing the direction of maximum extension, provides evidence for two possible mechanisms that can produce the observed microstructural features: anisotropic grain boundary migration and recrystallization; and anisotropic crystal growth. Anisotropic grain boundary migration and recrystallization are relatively common processes and they account for these common features in metamorphic tectonites (Blenkinsop 2000). However, although the recrystallization processes have important role in the formation of the anisotropic shape of grains in the tectonites studied (Castro 2007, Gonçalves and Lagoeiro $2009 \mathrm{~b}$ ), our study is focused on the evidence of fluidgrain interaction and its influence on the anisotropic syn-kinematic and static crystal growth.

The grain boundary and pore geometries suggest a fluid-solid interaction in these rocks and also indicate that static grain growth (involving grain boundary migration in the presence of fluid at relatively high temperature) might have been an important process during the evolution of microstructures in these rocks. The driving force for grain growth should be the reduction of the total grain boundary area (grain boundary area reduction - GBAR) (Vernon 1976, Poirier 1985), resulting in a reduction of the interfacial free energy for the aggregate. The grain boundary migration that accomplishes grain growth may be caused by the difference in free energy across the grain boundary curvature. The free energy difference makes a boundary move toward its center of curvature, causing small grains to decrease in size (and then disappear) and large ones to increase. The difference between the strain energy stored in adjacent grains could be the driving force for grain boundary migration, but as there are no optical features indicating differences in crystal plastic deformation between neighbor quartz grains, it should not play a major role in the process.

Static grain growth occurs when deformation decelerates or ceases, and the aggregate is not in a state of minimum free energy. Grains still contain dislocations and subgrains. At conditions with temperature relatively high and a large amount of fluid is present along grain boundaries, recovery, recrystallization and GBAR may occur until a configuration characterized by a state of minimum free energy can be reached. Under these conditions characterized by a state of hydrostatic stress, fluid distribution will be isotropic and so will favor the grain growth. The final aggregate will be comprised of grains of unimodal grain size. However, in the studied rocks the quartz grains have a relatively high aspect ratio (up to $4: 1$ depending on the hematite content) and the pore distribution along grain boundaries is highly anisotropic, which indicates that the grains have grown under nonhydrostatic stress conditions and constrained by platy hematite grains.

The anisotropy of interfacial energies and the nonhydrostatic stress on the aggregate produce significant deviations from the fluid distribution predicted by isotropic equilibrium theory and then it may be accounted for the anisotropic growth rates observed in the rocks studied (Heidug 1991, Tullis et al. 1996). Walff and Faul (1992) have shown that the anisotropy of interfacial energies can produce connected fluid distributions at some grain junctions but isolated pores at others. It is worth noting that the way in which fluids are distributed along grain boundaries depends on the nature of mineral interfaces. In this case, only phase boundaries (hematite-quartz) may yield a film fluid distribution (Fig. 5a - no pores were observed along these boundaries and no triangular features of hematite are impressed on quartz grain faces).

Hence, anisotropic grain growth is a result of heterogeneous fluid distribution along grain boundaries, which is caused by the differential stress and the presence of hematite. Oriented hematite plates that together with the slightly tabular quartz grains define the foliation have a profound effect on the nature of fluid distribution in these rocks. Hematite plates might have a role very similar to mica and other phyllosilicates in quartzite. It might maintain fluid along the interphase 
boundaries (hematite/fluid/quartz) even under high normal stress (Fig. 5a). Thus the presence of hematite enhances the wetting behavior of fluid, promoting the dissolution and increasing grain boundary diffusion rates at these interphase boundaries. The presence of fluid along the phase boundaries provides a faster diffusional transport path between hematite and quartz grains than in other interfaces.

The grain scale transport of aqueous fluids in the rocks studied depend on the nature of the grain boundaries as well as on the orientation of the grain boundaries with respect to the principal axes of the finite strain ellipsoid. Fluid-assisted diffusion on the phase boundaries (normal to the maximum compression direction) provides the rapid transport of material. On quartzquartz interfaces transport took place through an interconnected network of pores along three- and four-grain junctions. Quartz boundaries normal to the $X$-axis, preferentially rhombohedral and prismatic surfaces for the quartz crystals, are sites of fluid concentration and deposition (Fig. 5b). Thus quartz boundaries migrate preferentially parallel to the direction of maximum elongation. Therefore, mass transport is more effective parallel to the $X$-axis, resulting in faster grain growth in this direction corresponding to migration of boundaries whose poles make high angle with quartz $c$-axes. It is worth to note that it is opposite to growth condition of new precipitated quartz grains (Tullis 1989, Hippertt 1994).

Consequently, the shape preferred orientation observed in these rocks might not be exclusively attributed to recrystallization since anisotropic grain growth might have had a significant contribution to the development of aspect ratio of the grains. A similar result was achieved by Karato and Masuda (1989) in experimental deformation of wetted quartz aggregates carried out under differential stress. They found evidences for the formation of grain shape by anisotropic grain growth, as a result of anisotropic water distribution caused by a large differential stress.

\section{CONCLUSIONS}

Microstructural observations of quartz-hematite tectonites indicate that anisotropic fluid distribution and grain growth have exerted an important role on the fabric evolution of banded iron formation from Quadrilátero Fer- rífero (MG). Below are summarized the main conclusions of the present study.

(1) In addition to the anisotropic grain boundary migration and recrystallization, anisotropic dissolution and grain growth were responsible for the formation of hematite plates and tabular quartz grains contributing significantly to the generation of the penetrative foliation observed in these rocks.

(2) Based on pore distribution, fluid distribution was highly anisotropic. The anisotropy results from the nature of grain boundaries as well as the orientation of the finite strain axes. Although we cannot conclude about the nature of fluid distribution on pore-free flat surfaces oriented normal to the maximum compression direction, we interpret that these phase boundaries were wetted with a continuous fluid film, which might be important in the dissolution of both quartz and hematite grains, acting as faster diffusion pathway for transferring the dissolved material from the dissolution site to sites of precipitation. At quartz-quartz boundaries normal to the intermediate strain axis, fluids occur as isolated pores typically faceted, reflecting crystallographic control, close to quartz-quartz edges, characterizing a fluid interconnected network along three- and four-grain junctions on quartz-quartz interfaces.

(3) Quartz boundaries normal to the maximum elongation direction are sites of fluid concentration and precipitation. On these boundaries small oriented faceted hematite and quartz grains were precipitated in large irregular pores. Grain growth rates are faster parallel to the $X$-axis.

(4) The presence of hematite plates may have a strong effect on wetting behavior of fluid in these rocks in a manner similar to that of micas in quartzites. Hematite-quartz phase boundaries might have physical and chemical properties very different from quartz-quartz interfaces. Even under high normal stresses the phase boundaries might maintain a continuous fluid film, increasing greatly the diffusion rates along these boundaries. This condition allows a faster quartz crystal growth parallel to rhombohedral, trapezohedral and prismatic bound- 
aries, differently from what is proposed for new precipitated grains, which grow parallel to basal planes.

(5) In two distinct situations the presence of hematite influences the kinetics of quartz grain growth. First, small precipitated hematite grains may have a pinning effect on quartz grain boundary migration (boundaries facing the maximum elongation direction). Second, the mean grain size of host quartz grains is substantially smaller in domains with higher content of hematite.

\section{ACKNOWLEDGMENTS}

The authors are grateful to the anonymous reviewers for the helpful comments. We would like to thank the Fundação de Amparo à Pesquisa do Estado de Minas Gerais (FAPEMIG) and Coordenação de Aperfeiçoamento de Pessoal de Nível Superior (CAPES) for the financial support.

\section{RESUMO}

Muitos estudos têm demonstrado o efeito de uma segunda fase sobre a distribuição de fase fluida e dissolução de grãos de quartzo. Entretanto, como a maioria das observações vêm de agregados deformados sob condições de tensão hidrostática e em rochas quartzosas ricas em mica, a distribuição $3 \mathrm{D}$ de poros em bordas quartzo-quartzo (BQQ) e quartzo-hematita $(\mathrm{BQH})$ tem sido estudada. Várias superfícies de fraturas orientadas segundo o elipsóide de deformação finita foram analisadas. A distribuição dos poros caracteriza a porosidade e a forma dos grãos como altamente anisotrópicas, o que resulta da natureza e orientação das bordas. BQH têm propriedades físico/químicas muito diferentes de $\mathrm{BQQ}$, uma vez que as plaquetas de hematita têm forte efeito no comportamento do fluido, de maneira similar às micas em quartzitos. Elas são superfícies planas, livres de poros, normais à direção de máximo encurtamento, sugerindo que estiveram, em um momento, cobertas por um filme contínuo de fluido agindo como um caminho mais rápido de difusão. Nas BQQ, os poros são facetados, isolados, concentrados nos limites das mesmas refletindo o controle cristalográfico e uma rede interconectada de fluido ao longo das junções dos grãos. As BQQ normais à direção de máxima extensão são sítios de concentração de fluido. Como consequência, a dissolução anisotrópica e o cresci- mento de grãos foram responsáveis pela formação de plaquetas de hematita e grãos de quartzo tabulares contribuindo significativamente para a geração da foliação observada nas rochas estudadas.

Palavras-chave: mecanismos de deformação, distribuição de fluido, crescimento de grão, porosidade, transferência de solução.

\section{REFERENCES}

ALKMIM FF AND MARSHAK S. 1998. Transamazonian Orogeny in the Southern São Francisco Craton Region Minas Gerais Brazil: evidence for Paleoproterozoic collision and collapse in the Quadrilátero Ferrífero. Precambrian Res 90: 29-58.

Babinsk M, Chemale JR F AND VAN SChmus WR. 1993. A idade das formações ferríferas bandadas do Supergrupo Minas e sua correlação com aquelas da África do Sul e Austrália. In: ANAIS II SIMPÓSIO DO CRÁTON DO SÃO Francisco, Salvador, Soc Bras Geol, Núcleo Bahia/ Sergipe, p. 152-153.

BLENKINSOP TG. 2000. Deformation microstructures and mechanisms in minerals and rocks. Kluwer Academic Press, Dordrecht, The Netherlands, 169 p.

Carneiro MA, Noce CM And TeiXeira W. 1995. Evolução policíclica do Quadrilátero Ferrífero: Uma análise fundamentada no conhecimento atual da geocronologia U-PB e geoquímica isotópica Sm-Nd. Rev Esc Minas 48: 264-273.

Carneiro MA, TeiXeira W and Machado N. 1994. Geological evolution of a sialic Archean crustal fragment from Quadrilátero Ferrífero in eastern-central Brazil, based $\mathrm{U}-\mathrm{Pb}, \mathrm{Sm}-\mathrm{Nd}, \mathrm{Rb}-\mathrm{Sr}$ and $\mathrm{K}-\mathrm{Ar}$ isotopic constrains. Terra Nostra 2: 12-13.

Castro CP DE. 2007. Microestruturas e Textura de Equilíbrio em Quartzo Recristalizado. Dissertação de Mestrado, UFOP, Departamento de Geologia, 150 p. (Unpublished).

DAINES MJ AND Kohlstedt DL. 1997. Influence of deformation on melt topology in peridotites. J Geophys Res 102: 10257-10271.

DORR II JVN. 1969. Physiographic, stratigraphic and structural development of the Quadrilátero Ferriífero, Minas Gerais, Brazil. United States Geological Survey Prof. Paper 641-A. United States Geological Survey, p. 1-110

FARVER JR AND YUND RA. 1999. Oxygen bulk diffusion measurements and TEM characterization of a natural ultramylonite: implications for fluid transport in micabearing rocks. J Metam Geol 17: 669-683. 
GonçAlves CP DE C AND LAgOeIRo LE. 2009a. U-Stage and EBSD technique as complementary methods. Rev Bras Geoc 39(1): 112-128.

Gonçalves CP DE C ANd Lagoeiro LE. 2009b. Contrasting microfabrics in Banded Iron Formation, in Quadrilátero Ferrífero-MG, Brazil. In: Anais XII SNET Simpósio Nacional de Estudos Tectônicos, Ouro Preto, Soc Bras Geol, Núcleo Minas Gerais, 29 p.

HEIDUG WK. 1991. A thermodynamic analysis of the conditions of equilibrium at nonhydrostatically stressed and curved phase boundaries. J Geophys Res 96: 21909 21921.

Herz N. 1970. Gneissic and Igneous Rocks of the Quadrilátero Ferrífero, Minas Gerais, Brazil. United States Geological Survey Professional Paper 641-B.

Herz N. 1978. Metamorphic rocks of the Quadrilátero Ferrífero, Minas Gerais, Brazil. United States Geological Survey Professional Paper 641-C.

HiCKMAN SH AND EvANS B. 1995. Kinetics of pressure solution at halite-silica interfaces and intergranular clay films. J Geophys Res 100: 13113-13132.

HIPPERTT JF. 1993. Direct observation of porosity in quartzite and phyllonite. Neues Jarbuch für Mineralogie 166: 239-259.

HiPPERTT JF. 1994. Grain boundary microstructures in micaceous quartzite: significance for fluid movement and deformation processes in low metamorphic grade shear zones. J Geol 102: 331-348.

HippertT JF, Borba RP AND NALINI JR HA. 1992. O contato Quartzito Moeda-Complexo Bonfim: Uma zona de cisalhamento normal na borda oeste do Quadrilátero Ferrífero, MG. Rev Esc Minas 45: 32-34.

HiRTH G AND TUlLis J. 1991. The effect of porosity on the strength of quartz aggregates experimentally deformed in dislocation creep regime. Tectonophysics 200: 97-110.

Jin Z-M, GReEN HW AND ZhOU Y. 1994. Melt topology in partially molten mantle peridotite during ductile deformation. Nature 372: 164-167.

Jordt-Evangelista H, Alkmim FF And Marshak S. 1992. Metamorfismo Progressivo e a Ocorrência de três Polimorfos de $\mathrm{Al}_{2} \mathrm{SiO}_{5}$ (cianita, andaluzita, silimanita) na Formação Sabará em Ibirité, Quadrilátero Ferrífero, MG. Rev Esc Minas 45: 157-160.

KARATO S. 1989. Grain growth kinetics in olivine aggregates. Tectonophysics 168: 255-273.

KARATO S AND MasudA T. 1989. Anisotropic grain growth quartz aggregates under stress and its implication for foliation development. Geology 17: 695-698.
KRUhl JH AND PETERnEll M. 2002. The equilibration of high-angle grain boundaries in dynamically recrystallized quartz: the effect of crystallographic and temperature. J Struct Geol 24: 1125-1137.

LeE VW, MacKwell SJ And BRantley SL. 1991. The effect of fluid chemistry on wetting textures in Novaculite. J Geophys Res 96: 10023-10037.

Machado N AND CARneiro MA. 1992. U-Pb evidence of Late Archean tectonothermal activity in southern São Francisco shield, Brazil. Can J Earth Sci 29: 2341-2346.

Machado N, Schrank A, Noce CM and Gautier G. 1996. Ages of detrital zircon from Archean-Paleoproterozoic sequences: Implications for Greenstone Belt setting and evolution of a Transamazonian foreland basin in Quadrilátero Ferrífero, southeast Brazil. Earth and Planet Sci Lett 141: 259.

MANCKTELOW NS. 1987. Atypical textures in quartz veins from the Simplon Fault zone. J Struct Geol 9: 995-1006.

Marshak S, Alkmim FF and Jordt-Evangelista H. 1992. Proterozoic Crustal Extension and the Generation of Dome-and-Keel Structure in na Archean Granite-Greenstone Terrane. Nature 357: 491-493.

Noce CM. 1995. Geocronologia dos Eventos Magmáticos, Sedimentares e Metamórficos na Região do Quadrilátero Ferrífero, Minas Gerais. Tese de Doutorado, Instituto de Geociências, Universidade de São Paulo, 128 p.

O’Donoghue MI. 1987. Quartz. London, Butterworths, $225 \mathrm{p}$.

PASSCHIER CW AND TROUW RAJ. 1996. Microtectonics. Springer Berling, $2^{\text {nd }}, 289$ p.

PIRES FRM. 1995. Textural and Mineralogical variations during metamorphism of the proterozoic Itabira iron Formation in the Quadrilátero Ferrífero, Minas Gerais, Brazil. An Acad Bras Cienc 67: 77-105.

POIRIER JP. 1985. Creep of Crystals. Cambrigde University Press, Cambridge.

PRIOR DJ ET AL. 1999. The application of electron backscatter diffraction and orientation contrast imaging in the SEM to textural problems in rocks. Am Miner 84: 17411759.

RAJ R. 1982. Creep in polycrystalline aggregates by matter transport through a liquid phase. J Geophys Res 87: 4731-4739.

Renger FE, Noce CM, Romano AW And Machado N. 1995. Evolução Sedimentar do Supergrupo Minas: $500 \mathrm{Ma}$. de Registro Geológico no Quadrilátero Ferrífero, Minas Gerais, Brasil. Geonomos 2(1): 1-11. 
Rosière CA, SiEmes H, QuAde H, BROKMEIER HG AND JANSEN EM. 2001. Microstructure, texture and deformation mechanism in hematite. J Struct Geol 23: 1429-1440.

SPRY A. 1983. Metamorphic Textures. Pergamon Press., London, $352 \mathrm{p}$.

TEIXEIRA W. 1985. A evolução geotectônica da porção meridional do Cráton do São Francisco, com base em interpretações geocronológicas. Ph.D. Thesis, Universidade de São Paulo, São Paulo, Brasil.

Teixeira W, TAssinari CGG, Cordani UG and KaWASHITA K. 1989. A review of the geochronology of the Amazonian cratontectonic implications. Prec Res 42: 213-227.

TULLIS J AND YUND RA. 1982. Grain growth kinetics of quartz and calcite aggregates. J Geol 90: 301-318.

TUllis J, Yund R AND FARVER J. 1996. Deformationenhanced fluid distribution in feldspar aggregates and implications for ductile shear zones. Geology 24: 63-66.

TULLIS TE. 1989. Development of preferred orientation due to anisotropic dissolution/growth rates during solution transfer creep. Eos 70(15): 457.
Urai JL, Means WD And Lister GS. 1986. Dynamic recrystallization of minerals. Amer Geophys Union Geophys Monograph 36: 161-199.

VERNON RH. 1976. Metamorphic Processes: Reactions and Microstructure Development. George Allen and Unwin, London, $247 \mathrm{p}$.

WALFF HS AND FAUL UH. 1992. Effects of crystalline anisotropy on fluid distribution in ultramafic partial melts. J Geophys Res 97: 9003-9014.

WATSON EB AND BRENAN JM. 1987. Fluids in the lithospher, 1. Experimentally-determined wetting characteristics of $\mathrm{CO}_{2}-\mathrm{H}_{2} \mathrm{O}$ fludis and their implications for fluid transport, host-rock physical properties, and fluid inclusion formation. Earth Planet Sci Lett 85: 497-515.

Wegner MW AND Christie JM. 1983. Chemical etching of deformation sub-structures in quartz. Phys Chem Miner 9: 67-78. 